\title{
Por que escolher a Medicina de Família e Comunidade?
}

\author{
Ademir Lopes Júnior
}

\section{O que é a especialidade?}

A Medicina de Família e Comunidade (MFC) é a especialidade médica que cuida das pessoas ao longo do tempo, independente do problema de saúde, do sexo, da idade, ou do órgão afetado pela doença.A MFC visa o atendimento integral das pessoas, famílias e comunidade por meio decompetênciaspreventivas e terapêuticas.

O médico de família e comunidade (Mfc) é um especialista em atenção primária à saúde, portanto, deve ter formação geral que lhe permita ser o primeiro contato do paciente sempre que esse procure o serviço de saúde. É o profissional que coordena o cuidado ao longo do tempo com resolutividade de $85 \%$ a $95 \%$, além do manejo de sintomas inespecíficos.

O fortalecimento da MFC está diretamente vinculado a organização do sistema de saúde. Países com sistemas de saúde mais justos para toda a população têm forte atenção primária, com priorização do número de médicos com formação geral em relação aos demais especialistas.

No Brasil, embora a MFC seja reconhecida pelo Conselho Federal de Medicina desde 1981, apenas após a criação da Estratégia de Saúde da Família (ESF), em 1994, a especialidade tornou-se mais conhecida.

\section{Por que escolhi essa especialidade?}

Entrei na FMUSP em 2000. Não tive nenhuma disciplina sobre atenção primária na graduação -apenas apuericultura no Centro de Saúde-Escola do Butantã e uma visita domiciliar no PSF da Zona Leste. Aliás, lembro até hoje dessa visita: um paciente com

\section{Doença de Parkinson.}

A intensa grade curricular da FMUSP pouco permitiavivenciaroutros espaços. Por isso, "tranquei" a faculdade para conhecer um pouco da USP: entre o $3^{\circ}$ e $4^{\circ}$ ano parei por 6 meses o curso enquanto frequenteicomo ouvinte disciplinas nas Faculdades de Jornalismo, Psicologia e História.Durante o internato, "tranquei" mais três vezes: um mês de estágio de Medicina Tropical em Santarém, um mês de Geriatria no Canadá, e 15 dias de Oftalmologia e Otorrinolaringologia no HC-FMUSP (na época não haviam esses estágios). Ao todo, adiei em 9 meses minha formatura, e ainda restaram 2 meses para estudar para a prova de residência.

Apesar de já ter ouvido sobre a MFC no Brasil, apenas no Canadá conheci a prática de um Mfc. Isso me encantou: ser um profissional com ampla visão clínica evasto e variado repertório de pacientes. Mas como seria aqui no Brasil?

Para isso, fui visitar o programa de residência de MFC do Grupo Hospitalar Conceição no Rio Grande do Sul, um dos mais antigos do Brasil. Observei uma consulta não agendada de um paciente com lombalgia. A consulta foi muito diferente da queixaconduta que eu estava habituado!

O médico já conheciao paciente, perguntou o que lhe preocupava, entendeu suas dúvidas, investigou e orientou os hábitos posturais eacordou as possibilidades terapêuticas. A integralidade do cuidado se tornavareal ali na minha frente e em 10 minutos! Com o tempo, duranteminha residência, descobri que isso só era possível com a longitudinalidade e uso de "tecnologias leves"como a Medicina Centrada no Paciente ou do Teorema de Bayes.

Graduação em Medicina pela Universidade de São Paulo, Consultor da Secretaria de Gestão do Trabalho e Educação em Saúde do Ministério da Saúde, Membro da Câmara Técnica de Medicina da Família e Comunidade, Delegado do CREMESP. 
Nesse estágio, também observei a discussão sobre a dinâmica familiardeum paciente acamado com múltiplas morbidades cujacuidadora com depressão nãoaderia às orientações. $O$ que parecia um caos, ficou claro e passível de intervenção com o uso das ferramentas da abordagem familiar. E, assim, foi possível construir um plano terapêutico que ostornassem mais autônomospara seus próprios projetos de vida.

Acompanhei pacientes em cuidados paliativos, pré-natal, crianças com asma. A MFC não era uma simples somatória de outras especialidades, havia algo próprio! Além disso, em várias situaçõesna minha própria família e amigos (classe média) percebia o quanto fazia falta um profissionalpara coordenar o cuidado dos meus avós, pais e irmão.

$\mathrm{Na}$ minha graduação já havia pensado em fazer Pediatria, Geriatria, Psiquiatria e Infectologia. Mas como escolher? Conhecia inúmeros psiquiatras e pediatras com 30 anos de formação, mas nenhum Mfc! O que seria da MFC em 2040? Qual seria o risco de uma especialidade quasetodavinculada apenas ao sistema público? Teria alguma perspectiva financeira? Teria reconhecimento pelos meus pares que sempre desprestigiavam essa especialidade?

Mas a MFC era uma especialidade em franca ascensão. Eu poderia integrar a prática clínica com outras áreas do conhecimento. Gostava disso!Eu poderia conversar com as pessoas, conhecendo seus hábitos e história de vida nas suas casas e cotidiano. Havia grande diversidade de atuação: de insuficiência cardíaca aos déficits motores, de lesões de pele aos problemas de linguagem, das angústias com o ciclo de vida às crises psicóticas, da promoção à saúde à caquexia.

Os Mfc que conhecia erambastante requisitados nas universidades e serviços de saúde. Os programas de residência em MFC eram os que mais haviam se expandido no país. O ganho salarial, embora não fosse o maiorentre as especialidades, era razoável e com boas garantias. Com o tempo, percebi que a MFC me oferecia ampla possibilidade de atuação no sistema públicoou privado, nas grandes ou pequenas cidades, nas comunidades ou casas, nas instituições de saúde ou ensino. Havia muita tecnologia envolvida,seja no uso das habilidades comunicacionais oude informática e telemedicina. Havia um novo espaço a se construir e eu poderia ter muita satisfação nesse processo.

A MFC, enfim, não era uma especialidadede pobrespara pobres! Conheci experiências exitosas no próprio Brasil e quase todas as críticas ou descréditos à MFC vinham de outros especialistas que pouco ou nada conheciam da área. A ESF se consolidava, tanto que em 2011 a revista The Lancet publicou um número inteiro dedicado aos bons resultados da estratégia brasileira.

Resolvi arriscar e participar da criação de um novo momento no país. Apesardos desincentivos de TODOS os preceptores dos estágios do meu internato, optei pela MFC. Estaria participando da construção de uma especialidade que, apesar de reconhecida desde 1981, apenas agora era mais evidente no cenário nacional.

Durante a residência, fui para Portugal, conheci médicos da Espanha, Inglaterra e Bélgica. Percebi o quanto os MFC eram reconhecidos em outros países. Desde então, inúmeras oportunidades se abriram para mim, seja no ensino, gestão ou assistência à saúde.

Por fim, certamente essa é uma especialidade a ser considerada por aqueles que gostamda clínica ampliada, da relação médico-paciente, que acham interessante o corpo humano em sua totalidade, bem como para aqueles se interessam pelosvários momentos de vida em seus vários aspectos e contextos. Se você gostar de desafios, vale à pena conversar com alguém que fez a residência em MFC, certamente serão lhe apresentadas oportunidades e vários caminhos a serem construídos e desvendados. 